ISSN 1991- 8690

website:http://jsci.utq.edu.iq

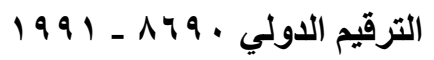

Email: utjsci@utq.edu.iq

\title{
Riverine Field Oil Spill Experiment
}

\author{
Manal Kamil Khalaf Al-Asadi \\ Marine Chemistry Dept. - Marine Science Center - University of Basra-IRAQ
}

\section{Abstract}

This study concern the case of oil spill in the river Shatt al-Arab- site (Muftia) to understand the environmental conditions affecting during the case of oil spill accident.

It was found that there is privacy in such environment, during exposure to spilled oil, considering that such areas are characterized by high water temperature, long day light, And a special bacterial activity.

To understand such circumstances affecting the spilled oil. A gas liquid chromatography technique was used by selection the n-alkanes in this crude oil, the analysis of their n-alkanes reduced in concentration from 370$93 \mathrm{ug} / \mathrm{g}$ in crude oil before spill to $12.00 \mathrm{ug} / \mathrm{g}$ after 164 days of spill oil by $96.77 \%$ removal.

$$
\begin{aligned}
& \text { التجربة العراقية لدراسة التسربات النفطية في الانهار }
\end{aligned}
$$

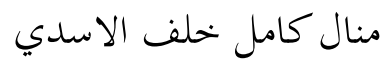

$$
\begin{aligned}
& \text { قسم كيمياء البيئة البحرية والتلوث - مركز علوم البحار -جامعة البصرة - العراق }
\end{aligned}
$$

تم دراسة حالة النسربات النفطية في نهر شط العرب- موقع المفتية لفهم الظروف البيئية المؤثرة اثثاء حالة تسرب النفط في حالة الحوادث حيث تبين ان هنالك خصوصية في متل هذه البيئات اثثاء تعرضها للنفط المنسرب باعتبار ان منل هذه المناطق تتميز بفترات ضياء طويلة

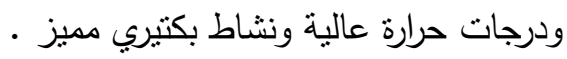

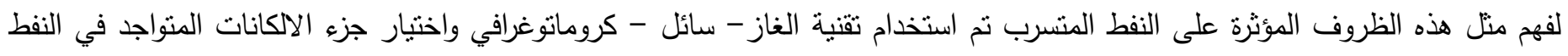

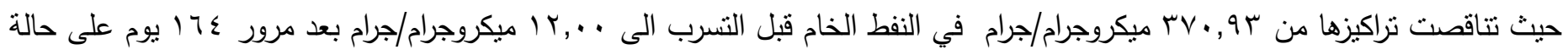

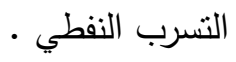




\section{Introduction}

Oil production, transportation and uses are heavily in the coastal regions and pollution therefore predominately affects the surface waters of the rivers, Photo-oxidation and biodegradation are the two most important factors involved in the transformation of crude oil or its products that are released into the environment. Natural microbial populations in seawater biodegraded $28 \%$ of crude oil within 8 weeks at $20 \mathrm{C}$ when sufficient nutrients were supplied to the sea water. It is concluded that susceptibility of crude oil to biodegradation is increased by its photo oxidation (Dutta and Harayama,2000)

The smaller day to day spills in the coastal waters and harbors produce chronic pollution that is much is larger in total volume and probably more severe in biological consequences.

Just after an oil spill on water, the major weathering factor acting on the oil is evaporation. Later, depending on the physical and chemical properties of the oil and on the environmental conditions (Regnier et.al., 1975).

The fate of oil in fresh water ecosystems in general and riverine oil Spills is scarcely investigated; the study by DouAbul and Al-Asadi (1990) was directed to understand the weathering of stranded oil deposited over river banks.

Local out door experiment study the changes of physico-chemical which alter the oil components was done by Al-Timari and Al-Imarah (1996).

Quantitative information on the weathering of spilled oil is essential to a fuller understanding of the fate and behavior of oil in the environment. Such data is also useful for spill modeling.

The composition and concentration changes of key components such as alkane were quantitatively correlated to evaporative loss.

Two opposing effects during evaporation-one is the loss of oil components due to evaporation, and another is build-up of oil components due to volume deduction-were examined.

So-called "pattern recognition" plots and these permitted deduction of a best of values for quantitation of exposure to evaporative weathering (Wang and Fingas, 1995)
But it Although the experimental spill in this study are small (2 barrels), its adequately represent for a chronic oil pollution in the region has dual objective for developing the methodology for investigating the fate of aliphatic hydrocarbons in a slick and for obtaining data on the rate of loss under natural environmental conditions.

\section{Experimental Spills}

It is interest to investigate the rates of disappearance of specific aliphatic components of crude oil slicks under natural conditions.

The site selected for the deployment booms is AlMoftia oil Terminal pier. This area was chosen because it represents a possible source of oil spill and served as the base of operations for the experiment.

Two pieces of Covalca oil booms deployed in a chosen site, two barrels of Basra crude API (33.9) was spilled and field observation was done, weathering of crude oil through $\mathrm{nC} 25$ was determined by capillary gas chromatography following method described by DouAbul \& AlAsadi (1990).

Oil samples from surface were collected by immersing glass test tube to a depth of $5 \mathrm{~cm}$ below the surface slicks then removed slowly.

Comparison of chromatograms of the surface slicks with the original oil shows weathering and alternations that occur in the above carbon range. For this purpose a perkin-Elmer Sigma 300 capillary gas chromatography was equipped with flame ionization detector (FID) and a split-split less mode injection port.

Quantification of peaks and identification of hydrocarbons in chromatograms was achieved by a perkin-Elmer computing integrator (model LC 1100).

The fused silica capillary column used was a wall coated open tubular (WCOT) 50X0.25 mm i.d.SE30 (methyl silicon).

Helium was employed as a carrier gas with a liner velocity of $75 \mathrm{~cm} / \mathrm{s}$ and a split ratio of 100/1, operting temperature for detector and injector was $350 \mathrm{C}^{\circ}$ and $300 \mathrm{C}^{\circ}$ respectively. 
The column oven was operated under temperatures programmed conditions $(2 \mathrm{C} / \mathrm{min})$ from $120 \mathrm{C}^{\circ}$ to $280 \mathrm{C}^{\circ}$ with an isothermal period $(30 \mathrm{~min})$ at the end.

\section{Results \& Discussion}

Only few oil spill testing has been conducted out side of test tanks and realizing the limitation of such kind of experiments, a large scale oil spill experiment was done to understand the behavior of oil under natural circumstances.

GLC and capillary GLC using flame ionization detector (FID) have been used to investigate a multitude of naturally occurring and simulated oil spills depending primarily upon comparisons of $n$ alkane and isoprenoid (Van Vleet, 1984).

Although these approaches met with various degrees of success, more volatile components cast suspicion on the usefulness some of these techniques.

Fig.(1) illustrate losses of lower boiling components in Basra crude oil analyzed by capillary GLC which represent weathering processes that have take place after the spill.

Table (1) shows the results of $n$-alkane in crude oil from $\mathrm{nC} 9$ to $\mathrm{nC} 25$ with total $370.93 \mathrm{ug} / \mathrm{g}$. This concentration was reduced by weathering through the experiment to $14.44 \mathrm{ug} / \mathrm{g}$ after only 30 minutes with a minimum value of $12.004 \mathrm{ug} / \mathrm{g}$ was observed after 82 days of exposure, then after 164 days of exposure the alkane level of $20.979 \mathrm{ug} / \mathrm{g}$.

The loss represents $96.10 \%$ of the initial crude oil concentration once spilled and reduced to $94.34 \%$ after 164 days of the experiment, this removal in agreement which obtained from out door experiment in which the loss removal reached to 85.24\% (Al-Asadi, 1996).The relative importance of the numerous weathering processes is influenced greatly by composition of spilled oil and the environmental factors such as turbulence and temperature (Gordon et.al., 1976).

The degradation pattern and rate of biodegradation were found to be dependent on the oil concentration and on the presence of nutrients. Faster rates were observed at lower oil concentrations, while the addition of nutrients greatly slowed the degradation of PAHs and enhanced the degradation of the saturates (Fayad \& Overton, 1995) and this study had also shown that the use of C17/pristine and C18/phytane ratios may underestimate the magnitude of oil biodegradation in the presence of micro-organisms .There is a need to monitor the changes in both saturates and aromatics hydrocarbons in order to assess the biodegradation of spilled oil. If changes in in one fraction were monitored, perdition of the effect on the other fractions of oil could not be made.

Prisatne/Phytane ratio $(\mathrm{Pr} / \mathrm{Ph})$ range from 1.333 to 0.576 after 82 days which is a good indicator for the high rate weathering for the spilled oil.

It is important to distinguish between patterns of distinct oil composition due to biodegradation, which is significantly different

From the pattern due to physical or short-term weathering, the oil composition changes due to biodegradation can be readily differentiated from those due to physical weathering (wang et.al.,1998).

The observation of individual boom performance in this experiment is within the requirement which needed for oil-holding capacity to protect water intakes in the Shatt Al-Arab River which meet some problems from oil transport activities.

Also, these field data can be used to calibrate verification of laboratory experiment. The parameters used in identification of oil spill have to be independent of weathering (Grimalt \& albaiges,1982).The analysis of crude oil under field conditions for this long period(more than 5 months) show the weathering mechanism which modify the distribution of alkane of the spilled oil in the aquatic environment.

Although alkanes are not particularly useful for determining the sources of the spill, they can give some information on the degree of weathering (wang et al., 2011)

This paper described an analytical approach using hydrocarbon distribution pattern recognition and diagnostic ratios of source-specific marker 
compounds for the characterization of chemical composition and source identification of the spilled oil in the shatt Al-Arab river environment.

So, these data play an important role for preparing the oil print tool for this unique environment to assess the degree of oil pollution which reached and it is possible to modulate these data to predict the fate of spilled oil.

Table (1) variation of normal alkane -relative concentration for crude oil during field experiment

\begin{tabular}{|c|c|c|c|c|c|}
\hline $\begin{array}{c}\text { Normal alkanes } \\
+ \text { isoprenoids }\end{array}$ & $\begin{array}{l}\text { Regular Basra } \\
\text { crude oil (ug/g) }\end{array}$ & $\begin{array}{c}\text { After spilled } \\
\text { (30 min Exposure) }\end{array}$ & $\begin{array}{l}37 \text { days of } \\
\text { Exposure }\end{array}$ & $\begin{array}{l}82 \text { days of } \\
\text { Exposure }\end{array}$ & $\begin{array}{c}164 \text { days of } \\
\text { Exposure }\end{array}$ \\
\hline $\mathrm{nC}_{9}$ & 45.025 & 0.723 & N.D & N.D & N.D \\
\hline $\mathrm{nc}_{10}$ & 41.511 & 0.954 & N.D & N.D & N.D \\
\hline $\mathrm{nc}_{11}$ & 40.230 & 1.163 & N.D & N.D & N.D \\
\hline $\mathrm{nc}_{12}$ & 30.505 & 1.113 & N.D & N.D & N.D \\
\hline $\mathrm{nc}_{13}$ & 29.112 & 0.819 & 0.167 & N.D & N.D \\
\hline $\mathrm{nc}_{14}$ & 27.252 & 1.020 & 0.908 & N.D & N.D \\
\hline $\mathrm{nc}_{15}$ & 25.230 & 0.881 & 1.214 & 0.504 & 0.309 \\
\hline $\mathrm{nc}_{16}$ & 18.190 & 0.718 & 1.370 & 0.951 & 0.649 \\
\hline $\mathrm{nc}_{17}$ & 18.390 & 0.992 & 1.295 & 1.158 & 1.577 \\
\hline Pristane (pr) & 6.717 & 0.881 & 0.801 & 0.603 & 1.132 \\
\hline $\mathrm{nc}_{18}$ & 16.512 & 0.667 & 1.353 & 1.224 & 1.943 \\
\hline Phytane (ph) & 7.822 & 0.714 & 0.970 & 1.046 & 0.956 \\
\hline $\mathrm{nc}_{19}$ & 13.910 & 0.976 & 1.270 & 1.69 & 2.002 \\
\hline $\mathrm{nc}_{20}$ & 12.112 & 0.630 & 1.175 & 1.140 & 1.211 \\
\hline $\mathrm{nc}_{21}$ & 10.501 & 0.549 & 0.298 & 0.978 & 2.791 \\
\hline$n c_{22}$ & 10.151 & 0.522 & 0.772 & 0.793 & 2.537 \\
\hline $\mathrm{nc}_{23}$ & 8.205 & 0.609 & 0.703 & 1.014 & 4.757 \\
\hline $\mathrm{nc}_{24}$ & 4.990 & 0.511 & 1.065 & 0.865 & 0.713 \\
\hline $\mathrm{nc}_{25}$ & 4.565 & - & 0.685 & 0.559 & 0.402 \\
\hline Total & 370.93 & 14.444 & 14.046 & 12.004 & 20.979 \\
\hline Pr./Ph.ratio & 2.351 & 1.333 & 0.825 & 0.576 & 1.184 \\
\hline$\sum \mathrm{nC}$ odd & 195.168 & 6.712 & 5.632 & 5.903 & 11.838 \\
\hline$\sum \mathrm{nC}$ Even & 166.218 & 6.135 & 6.643 & 4.973 & 7.053 \\
\hline
\end{tabular}

N.D. Below the detection limit 


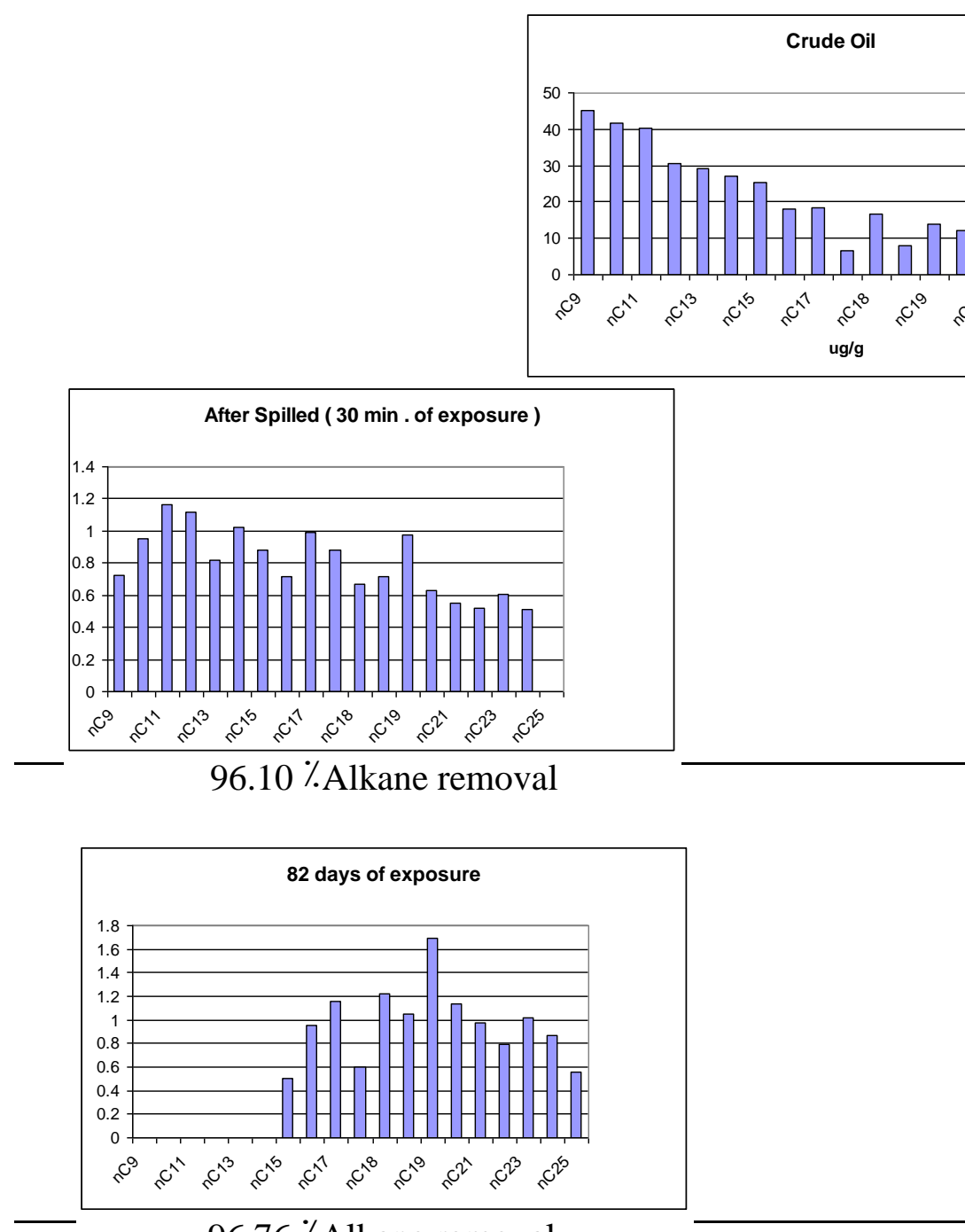

$96.76 \%$ Alkane removal

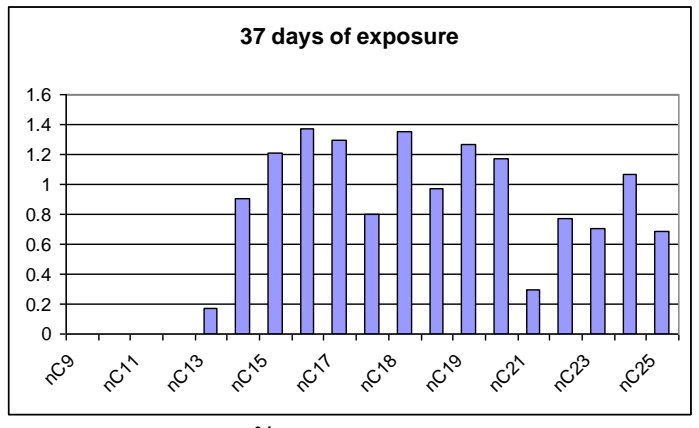

$96.21 \%$.Alkane removal

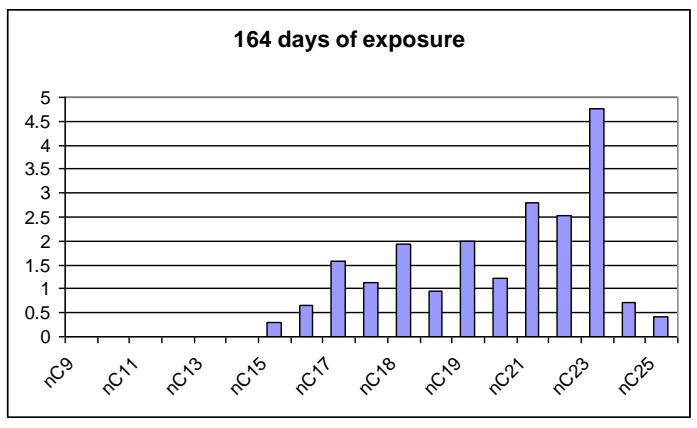

$94.34 \%$ Alkane removal

Fig.1 show weathering of crude oil during the field experiment

\section{Acknowledgement}

This project had received partial support from Southern Iraqi Company which the author highly appreciate their kindest help and encouragement given throughout the course.

\section{References}

Al-Taei, S. A. R.2010. Applied two dimensional model for oil spill movement in Khor AlZubair and Khor Abdulla, North West Arabian Gulf .Ph.D.Thesis, University of Basra.Iraq. 159
Al-Asadi, M.K. 1996. Fate of spilled oil under conditions of N.W.Arabian Gulf. Ph.D. Thesis, University of Basrah. Basrah.Iraq, $122 \mathrm{P}$.

Al-Timari, A. A.K. \& Al-Imarah, J.M. 1996. Weathering effect upon physicochemical parameters of oil spilled Stimulated on fresh water.Marina Mesopotamica, 11(1): 139-152. 
Blumer, M., Howard, L. Sanders, j., Grassle, F., Hamposon, G. R. 1971. A small oil spill. Environment, 13 (2):2-12.

Douabul, A. A. Z. \& Al-Asadi, M.K. 1990. Oil spill in rivers-Weathering of stranded crude. Marine Mesopotamica, 5(2): 293-303.

Dutta, T.\& Harayama,S.2000. Fate of crude oil by the combination of photo oxidation and biodegradation. Environmental Science and Technology, 34(8):1500-1505.

Fayad, N. M. \& Overton, E. 1995. A unique biodegradation Pattern of the oil spilled during the 1991 Gulf war. Marinen pollution Bulletin, 30 (1): 239-246.

Glover, C. J.and Jerry A.Bullin.1989.Identification of heavy residual oils by GC and GC- MS. Journal of environmental science and health, A 24(1):57-75.

Gordon, N. M., Keizer, P. D. Jr., Hardstyff, W. R, \& Aldow, D.G. 1976. Fate of crude oil spilled on sea waters contained in Outdoor tanks.Environmental Science and Technology 10(6): 580-585.

Grimalt, J. \& Albaiges, J. 1982. Oil spill identification by high Speed HPLC Journal of high Resolution chromatography 5: 255-259.

Rignier, Z. R., \& Scot, B.F. 1975. Evaporation rates of oil Components. Environmental Science and Technology. 9 (5):469-472.

Van Vleet, E.S. 1984. Fingerprinting oil spills in the marine Environment .Marine Technology Society, 18(3):11-23.

Wang,C.,Jianguo Du,Xuelu Gao, Yi Duan, Yanqing Sheng.2011.Chemical characterization of naturally weathered oil residue in the sediment from Yellow River Delta. China .Marine pollution Bulletin, 62:2469-2475.

Wang, Z. \& Fingas, M.1995.Study of the effects of weathering on the chemical composition of a light crude oil using GC/MSGC/FID. Journal of Micro column separations,7(6): 617-639.

Wang, Z., Fingas, M., Blenkinsopp, S., Sergy, G., Landriault, M., Sigouin, L., Foght, J., Semple, K.\& Westlake, D.1998.Comparison of oil composition changes due to Biodegradation and physical weathering in different oil. Journal of chromatography A, 809(1-2):89-107. 